\title{
Divine Love and the Negotiation of Emotions in Early Modern English Convents
}

\author{
Laurence Lux-Sterritt
}

... no love is true but that which is in Him, and for Him, and without impediment to His love. All other loves are false, slippery, perverse, and vain, as not being founded in God, the ground of all true and happy love. ${ }^{1}$

Thus wrote Gertrude More $^{2}$ on the subject of divine love, a spiritual emotion she described as antithetical with its earthly counterpart and which, to her, was the source of all other godly feelings. Her dual interpretation of 'good' and 'bad' emotions owed much to the widely held belief, derived from Ss Augustine and Thomas Aquinas, that 'passions' were symptoms which emanated from the body in order to manifest the disorders of the soul. This perception was a direct consequence of the anthropology of the age, which often opposed the spiritual to the carnal. It suggested that there were two types of emotions: bodily (or worldly) emotions, which were deemed dangerous, and spiritual emotions, which appeared valuable.

The study of emotions has recently become the focus of interest in research centres worldwide. ${ }^{3}$ It has attracted funding from the most prestigious awarding bodies and generated a wealth of excellent publications exploring the new field of 'emotionology'. ${ }^{4}$ The lens of emotions studies

1 The Writings of Dame Gertrude More, ed. by Benedict Weld-Blundell (London, 1910), p. 149.

2 Gertrude More (1625-33), CB137.

3 To cite but a few: Australian Research Council Centre of Excellence for the Studies of Emotions (University of Western Australia, dir. Philippa Maddern); Centre for the History of the Emotions (Queen Mary, University of London, dir. Thomas Dixon); CHEP ('An International Network for the Cultural History of Emotions in Premodernity'); and EMMA ('Pour une anthropologie historique des émotions au Moyen Âge', dir. Damien Boquet and Piroska Nagy).

4 Amongst many others, these general publications on emotions in history are most useful: Lucien Febvre, 'La sensibilité et l'histoire: Comment reconstituer la vie affective d'autrefois?', Annales d'histoire sociale 3.1/2 (1941): pp. 5-20; Daniel M. Gross, The Secret History of Emotion: From Aristotle's Rhetoric to Modern Brain Science (Chicago, IL, 
has been used to offer new readings of religious experience(s) in general, and I believe it can yield new and revealing insights into the history of early modern nuns. ${ }^{5}$ This chapter explores the affectivity of the English Benedictine nuns in exile in the seventeenth century in the Southern Netherlands and in France, and relies mostly on documents which belonged to the houses at Cambrai and Paris. ${ }^{6}$ Many were never expected to be read beyond the walls of the enclosure. ${ }^{7}$ I have deliberately chosen to quote them abundantly, in the hope of allowing the nuns' voices to speak out for themselves, on that most intimate subject of emotions.

In conventual writings, the 'terrene' affections which emanated from the senses and gratified the appetites were unanimously condemned, whilst only one emotion was praised as holy and spiritual: that of divine love. Zealous contemplative nuns embarked upon a personal crusade against their natural emotions, which they envisaged as obstacles separating them from their divine lover. To achieve their goal, these nuns had to die to the world and to themselves, forsaking any interaction with mundane society and abandoning any sense of their own self-worth. In order to meet such stringent demands, religious women followed various paths, and whilst some found solace in the Jesuit Spiritual Exercises, others such as the Benedictines of Cambrai adopted different types of spiritual techniques to tame their worldly emotions. Yet regardless of the methods they chose, all nuns strove towards the same goal: they hoped to become strangers to the world and to themselves, in order to become wholly available to divine love. Only then, once they were free of all human feelings, could these contemplatives experience perfect union with their heavenly bridegroom.

2006); William M. Reddy, 'Historical Research on the Self and Emotions', Emotion Review, 1.4 (2009): pp. 302-15, and The Navigation of Feeling: A Framework for the History of Emotions (Cambridge, 2001); Barbara H. Rosenwein, 'Worrying about Emotions in History', American Historical Review, 107.3 (2002): pp. 821-45; Richard Soradji, Emotion and Peace of Mind: From Stoic Agitation to Christian Temptation (Oxford, 2000). See also Peter and Carol Stearns, 'Emotionology: Clarifying the History of Emotions and Emotional Standards', American Historical Review, 90 (1985): pp. 813-36.

5 The modern taxonomy of 'emotions' is used in this chapter as a general term, although the primary sources documenting seventeenth century convents preferred terms such as 'affects', 'appetites', 'passions' or 'humours', which all convey similar, though not strictly identical meanings.

6 The Order first settled in Brussels in 1598. This was followed chronologically by another foundation in Cambrai (1623 - under the authority of the English Benedictine Congregation), Ghent (1624), Paris (1650), Boulogne (1652, relocated to Pontoise in 1658), Dunkirk (1662) and Ypres (1665). Ypres ultimately became an Irish house.

7 On the functions of reading and writing in the convent, see Heather Wolfe, 'Reading Bells and Loose Papers: Reading and Writing Practices of the English Benedictine Nuns of Cambrai and Paris', in Victoria E. Burke and Jonathan Gibson (eds), Early Modern Women's Manuscript Writing (Aldershot, 2004), pp. 135-56. 


\section{The Badge of Contemplative Perfection: Dying to the World, to Others and to Oneself}

'Oh, that I could esteeme all things as dunge and filth!': such was Gertrude More's cry, as she expressed her determination to feel nothing but disgust for earthly matters. ${ }^{8}$ Yet in that very exclamation, the tension is clear between her godly intentions to detest the world and her natural tendencies to cling to it despite herself. The personal writings of her sisters at Cambrai show that these feelings were shared by others in the community. How could one hope to know the divine love of God if she remained hindered by lowly human affections? This seemingly unsolvable problem was at the core of all religious life, and especially of female contemplative life, since early modern standards credited women with a more sensual and emotive nature than men.

The Catholic Reformation reflected these gendered prejudices when it extended its conception of male religious life to include new, active forms of life, whilst on the contrary reinforcing strict medieval rules for all female religious. In convents, everything was devised in order to curtail women's reputed natural inclinations to sensual pleasures and to mitigate their emotional weakness. When they joined contemplative communities, women became enclosed in accordance with the 1563 decree of the Council of Trent, later strengthened by Pius V's 1566 constitution Circa Pastoralis. As new English convents settled in Northern France and in the Spanish Netherlands, ${ }^{9}$ they had to adapt the architecture of the buildings they purchased to ensure a complete physical separation from the outside world: high walls were built around the houses and gardens, bars were added to windows, parlours were fitted with grates draped in cloth. ${ }^{10}$ The passing of small items was negotiated through 'turns', ingenious swivelling devices which permitted the exchange of goods without any contact between the people involved. ${ }^{11}$

8 Gertrude More, The Holy practices of a Devine Lover, or the Sainctly Ideots Devotions (Paris, 1657), p. 262.

9 The only exception was the house of Syon, a Bridgettine foundation which settled in Lisbon.

10 On the difficulties of some of these adaptations, see Caroline Bowden, 'Community Space and Cultural Transmission: Formation and Schooling in English Enclosed Convents in the Seventeenth Century', History of Education, 34.4 (July 2005): pp. 365-86.

11 In the Constitutions of the Benedictine houses, the chapter on enclosure occupies an important place. See the Brussels Statutes Compyled for the Better Observation of the Holy Rule of the Most Glorious Father and Patriarch S. Benedict (Ghent, 1632), chapter 5 , 'Of the Inclosure', pp. 18-22. The terms of the enclosure appear particularly rigorous in the Constitutions pour l'observance de la règle du glorieux père et patriarche sainct Benoist, dans le monastère des religieuses bénédictines angloises du titre de Notre-Dame de BonneEspérance, sous la supériorité de Monseigneur l'éminentissime cardinal de Retz, archevêque de Paris, et ses successeurs, Bibliothèque Mazarine, Paris, Ms 3326. 
But the idea of separation from the world applied to more than geographical location. The link with the outside had to be broken psychologically as well as spatially; correspondence, the exchange of gifts, even conversations were limited to the minimum and then only under the supervision of the abbess or the prioress. ${ }^{12}$ Such stringent rules were meant to ensure that new entrants 'died to the world' and abandoned the worldly affectivity which was deemed incompatible with the vocation of a contemplative nun. ${ }^{13}$

In his vivid depiction of life in the Franciscan Dutch convent of Bethlehem in Louvain, Craig Harline showed the dire consequences of laxity in this field: enslaved by their affection for the people they had left behind, indiscreet nuns spent their days at the grate and favoured human company over divine contemplation. Their levity caused public scandal but also affected the convent from within when their unbridled worldliness divided the community into cliques and factions. ${ }^{14}$ In order to avoid such pitfalls and prepare for divine love, nuns were encouraged to go much further than simply shun the outside world: they had to abandon mundane attitudes even inside the cloister. Prescriptive literature warned them against the dangers of particular friendships (or any particular enmities) and demanded they show the same indifference to one and all. ${ }^{15}$ One of the English Benedictines from Cambrai testified to the difficulty of such detachment when she confessed her inability to break her friendship with one of her sisters and asked for spiritual guidance on the matter. She felt guilty about this relationship which, although born inside the convent

12 See chapter 40 of the Benedictine Rule, 'How it is Unlawfull for the Sisters to give or receave any letters or Presents', or chapter 9, 'Of letters and Messages', of the Brussels Statutes; yet, Claire Walker has shown the remarkable discrepancy between the Rule, or the clerical instructions which prohibited correspondence as a threat to the nuns' commitment to enclosure, and the reality of cloisters' epistolary activities. See "Doe not Supose me a Well Mortifyed Nun Dead to the World”: Letter-Writing in Early Modern English Convents', in J. Daybell (ed.), Early Modern Women's Letter Writing 1450-1700 (Basingstoke, 2001), pp. 159-76.

13 If dying to the world was the ideal of a spiritual life, it was rarely possible to achieve it fully; publications have shown that nuns maintained daily commerce with the outside to ensure the survival of their institutions, and sometimes even to support the Catholic cause outside the convent. For the English Benedictines, see, for instance, Caroline Bowden, 'The Abbess and Mrs Brown: Lady Mary Knatchbull and Royalist Politics in Flanders in the Late 1650s', Recusant History, 24.3 (1999): pp. 288-308; Claire Walker, 'Prayer, Patronage, and Political Conspiracy: English Nuns and the Restoration', The Historical Journal, 43.1 (2000): pp. 1-23 and 'Loyal and Dutiful Subjects: English Nuns and Stuart Politics', in James Daybell (ed.), Women and Politics in Early Modern England, 1450-1700 (Aldershot, 2004), pp. 228-42; or Heather Wolfe, 'Dame Barbara Constable: Catholic Antiquarian, Advisor and Closet Missionary', in R. Corthell, F.E. Dolan, C. Highley and A.F. Marotti (eds), Catholic Culture in Early Modern England (Notre Dame, IN, 2007), pp. 158-88.

14 Craig Harline, The Burden of Sister Margaret. Inside a $17^{\text {th }}$-Century Convent (New York, 2000).

15 See the Benedictine Rule, chapters 53 and 56. 
walls, remained of the same nature as the worldly passions of the secular world. The reply she received was virulent, to say the least: its author took on the voice of God and, in this persona, reproved the penitent:

... through a complacence which she hath for a gentlewoman that is in the convent ... she loves better to comply with her then me $\&$ to be tyed to her then me. When this creature comes to see her in her cell, she chases me away from her to receave her, $\&$ she thinkes no more on me, but thinkes only of deverting herselfe with her ... Thus they spoyle one another, \& incourage one another to love the world, instead of incouraging one another to love nothing but me. ${ }^{16}$

This passage illustrates why it was so essential that a religious woman should die to all other creatures: her passions 'spoiled' her, they contradicted the very raison d'être of her religious vocation, since they distracted the soul from God. Interestingly, the object of the nun's affection is referred to as a 'gentlewoman' rather than a nun. She may have been a secular woman boarding for a time with the nuns, but it is equally possible that the term was used slightingly as an indictment of the worldly temperament of a woman who should have been more spiritually inclined.

The perfect religious was supposed to consider secular affectivity as incompatible with her godly vocation. In Cambrai, Gertrude More made it clear that earthly love turned the soul into 'a slave' of passions. ${ }^{17}$ God only should be the object of a nun's emotions, whilst she should remain indifferent to everything else: 'Shall I any more be so miserable as, by loving, having, adhering to, or desiring any created thing, to become estranged from Thee, in Whom I have placed all my hope, love, and desire?'18 These feelings were shared by her co-sister, Margaret Gascoigne, ${ }^{19}$ who was determined to free her soul of worldly attachments:

O love, how strong art thou! Thou, O love, I say, that wast able to draw my Saviour \& Redeemer into this vaile of miserie; when wilt thou forcibly draw me from the love of earthly and faiding things, \& farther from the inordinate $\&$ pestilent love of my owne selfe that is the root and spring of all other my corrupt \& vitious love? 20

16 Archives départementales du Nord (hereinafter ADN), Lille, Ms 20H-43: Just reproaches of our Lord to a soule who will not free herselfe from the love of a creature, nor herselfe. Considerations to love our Lord, \& that a creature is unworthy to be loved by us for her owne sake, or in regard of herselfe.

17 The Writings of Dame Gertrude More, p. 20.

18 Ibid., p. 13.

19 Margaret Gascoigne (1629-37), CB077.

20 Ibid., p. 66. 
Those were strong words, opposing divine union to a human love which was described here as 'corrupt' and 'vicious': it was an animal emotion born from the baser instincts of flawed, carnal individuals who sought nothing but their own gratification. Such emotions were not only considered misdirected, they were to be shunned as degenerate and sinful. And as Gascoigne's quotation indicates, the root of such evil was to be found in the most 'pestilent' sort of love, which was the love of oneself.

Thus, in the same way as nuns died to the world outside and to other people, they also endeavoured to leave behind their secular selves and their emotional weaknesses. Their new names in religion, which replaced those they were given at birth, symbolized the death of their secular beings and the birth of a new religious identity inspired by the holiness of the saint whose name was adopted. In the cloister, the self was to be progressively subdued in order to allow nuns to become blank slates on which the divine spirit would inscribe its will. This could be achieved through mortification of the senses (through physical asceticism), as well as the humiliation of emotions (through moral asceticism). It required constant effort on the part of the nun, who was to wield a daily battle against temptations. Christina Brent, ${ }^{21}$ who served as abbess of the Cambrai Benedictines between 1641 and 1645 and again from 1677 to 1681, wrote soliloquies in which her intellect warned her soul of the dangers to which it was exposed. The soul's enemies, she wrote, were 'the world, the divill and our owne sensuality'. Freeing one's soul from these perils was 'the payne upon which in effect all our successes depend'. ${ }^{22}$ Acutely aware that affections were natural to her, she urged her soul to embrace this fight with unfailing courage. From the moment she became a novice, Christina Brent viewed her vocation in terms of hardship and struggle:

Our life is truly said to be a warfare upon earth, there being a continuall combat to be undertaken against the world and the divill besides our owne evill affections \& unruly passions which joyne with our enemies, in which respect it is necessarie to be ever armed both with expectations of difficulties and resolution to go through them, always calling to mind that glorious victories are only gained in hard enterprises .... . ${ }^{23}$

Thus, the pursuits of a religious woman became shrouded with the aura of a mystical quest, a mission in enemy territory. One was to fight every moment of every day to overcome one's 'passions' and navigate through a minefield of temptations and sins.

\footnotetext{
21 Christina Brent (1629-81), CB015.

22 ADN, Ms 20H-10, f. 771.

23 ADN, Ms 20H-10, Reflexions when she was Novice, f. 815.
} 
Conventual manuscripts portrayed emotions as factors disrupting a life which was otherwise regulated in its smallest details. ${ }^{24}$ Such disorders, emanating from the body, were impediments to a contemplative vocation. Christina Brent even compared those who followed their worldly feelings to horses and mules and chastised them for 'becoming slaves to creatures, lyeing, groveling in the base filth of earthly pleasures, no otherwise then as beasts following their sensuall Appetites, or rather being inthralled unto them'. ${ }^{25}$ To her, those religious who slavishly complied with the demands of what she called 'the inferior portion of the soule' betrayed their very purpose in life; they partook of the great lie which gave false value to earthly things. ${ }^{26}$ As such, they were guilty of abandoning God's design for them by not exercising the spiritual or intellectual portion of their souls.

Similar opinions were voiced by many nuns, and echoed clerical treatises. ${ }^{27}$ When the prioress of the Paris community, Justina of Santa Maria Gascoigne ${ }^{28}$ encouraged her sisters 'to forsake \& renounce your selfe', and 'to [1]earne to acustome your selfe to mortifie your undue inclinations \& affections'. ${ }^{29}$ In order to domesticate 'unruly passions', religious women must mortify natural feelings such as 'anger, impatience, melancholy, fear, or scrupulosity' and cultivate 'peace, tranquillity, and cheerfulness, not suffering passions to be raised in our mind'. ${ }^{30}$

\section{Paths to Contemplative Perfection: Choosing One’s Way to God}

The raison d'être of any contemplative vocation was to forsake one's personal affective bonds to the world in order to give oneself entirely to God. As they endeavoured to shake off the shackles of earthly emotions, religious women were helped by a great abundance of prescriptive literature and clerical guidelines. Most influential were the three monastic vows of poverty, chastity and obedience, designed to guard nuns against sin, and to which the Benedictines added a fourth promise of 'conversion of [their]

24 St Augustine, bishop of Hippo (354-430) and St Thomas Aquinas (1224-74) strongly influenced the early modern approach to emotions.

25 ADN, Ms 20H-10, f. 781.

26 Ibid., f. 783.

27 See Book II, chapter IX on 'The mortification of the affections' by Augustine Baker, in Contemplative Prayer: Ven. Father Augustine Baker's Teaching thereon from "Sancta Sophia”, ed. by Benedict Weld-Blundell (London, 1907), pp. 138-40.

28 Justina of Santa Maria Gascoigne (1638-90), CB075.

29 Colwich Abbey, Ms H71, Justina Gascoigne's Instructions to Chapter, ff. 38-39.

30 Augustine Baker, in Contemplative Prayer, Weld-Blundell, p. 70. 
manners'. ${ }^{31}$ At Cambrai, Christina Brent referred to these four vows in martial terms, as weapons which allowed her nuns to win their battle against their worst enemies. ${ }^{32}$ The goal was to crucify the flesh through abnegation and a 'mortification of the senses'. ${ }^{33}$

The vow of chastity 'disengages $\&$ purifies the heart from sensuall $\&$ carnall affections'; ${ }^{34}$ what is meant by chastity here does not encompass sexual urges only, but all sensuality. It is well-known that, in some Orders, particularly zealous individuals acted against their bodies with sometimes troubling violence. Some ate only the leftovers of their sisters' meals. Others poured ashes on their portions to spoil the taste and quenched their thirst only with vinegar. Others still used the discipline until their habits and the walls of their cells were stained in blood. ${ }^{35}$ On the other hand, English Benedictines generally (and those in Cambrai more specifically) appear to have been somewhat wary of such excesses, which could cause overzealous nuns to think themselves more deserving than their sisters. ${ }^{36}$ With few exceptions, the English Dames preferred less ostentatious exercises of abstinence, whose only goal was to please God in all humility, through His will rather than their own. Such abnegation aimed at freeing nuns from their own self-will and vanquishing all sense of their own selfworth; it was a form of spiritual obedience to God.

In a manual destined for the novices at Cambrai, the author reminded new recruits that the vow of poverty was also a precious ally in the humiliation of the self. Since most English Benedictines came from the upper echelons of society, they had been raised with a certain sense of their social worth; many were used to being addressed with deference and enjoyed delicate apparel as well as the finer things in life. ${ }^{37}$ When they abandoned these privileges to enter the convent, they became equal in religion to the other choir sisters, their private property became communal and their natural pride was chastised.

31 See, for instance, ADN, Ms 20H-11: 'Povertie, Chastitie and Obedience and Conversion of my manners', profession of faith by Joan Seller, 20 March 1631 at Cambrai.

32 ADN, Ms 20H-10: 'It is an empire conquest commaund not over men but the spiritual enemies of our souls, the world, the flesh, the divill, by a religious poverty, chastitie and obedience.'

33 ADN, Ms 20H-37, Love of God, f. 145.

34 ADN, Ms 20H-17, A Short Treatise on the Three Principall Vertues and Vows of Religious Persons, ff. 129-130.

35 See my Redefining Female Religious Life: French Ursulines and English Ladies in Seventeenth-Century Catholicism (Aldershot, 2005), pp. 168-74.

36 ADN, Ms 20H-31, Advice to Beginners.

37 See the Brussels Statutes, chapter 2, 'Of Povertie', pp. 11-14. See also Silvia Evangelisti's study of Italian convents, 'Monastic Poverty and Material Culture in Early Modern Italian Convents', Historical Journal, 47.1 (2004): pp. 1-20. 
Moreover, monastic vows were buttressed by clerical guidance on how to tame natural inclinations. Nuns were taught to rely upon the counsel of their directors and advised never to enter into any spiritual exercises unsupervised since, despite their good intentions, the outcome was likely to be blighted by their flawed nature. They were warned that, if they relied on their own decisions, they would misuse their time according to "their fancy' and stray in their choice of books or their practice of meditation. They would not see 'their vices, their Passions and spiritual necessities which, for want of that assistance, lurk in them undiscovered or if seen they appear in borrowed dresses, which self love never fails to clothe them with'. ${ }^{38}$ It was taken as a universal truth that clerical guidance was crucial to the progress of religious women.

Jesuit direction was in great demand in continental convents in the post-Trent Spanish Netherlands and France. This did not apply only to active congregations, but also to enclosed teaching Orders and sometimes to more traditionally contemplative institutions. ${ }^{39}$ In the particular context of English Catholicism, it also seems likely that many nuns would have had prior experience of Jesuit confessors at home, in their recusant circles; amongst the Benedictines, several sisters counted Jesuits amongst their close kin. It is therefore not surprising that many Benedictine convents should have relied on Jesuit directors and spirituality, especially since several of them were founded before the revival of the English Benedictine Congregation. ${ }^{40}$

However, supervision by Jesuit directors did not suit all nuns, especially when, with time, the initial flexibility of Loyola's Exercises evolved towards a set method of meditation which tended to exclude mystical forms of spirituality. ${ }^{41}$ Amongst the English Benedictines, some communities argued about the thorny issue of spiritual directors. Although the house in

38 ADN, Ms 20H-28, Directions for the Retreat.

39 The Jesuit example influenced the missionary vocation of Mary Ward's institute; see M.C.E. Chambers, The Life of Mary Ward (1585-1645), 2 vols (London, 1882-85); Henriette Peters, Mary Ward: A World in Contemplation, trans. by Helen Butterworth (Leominster, 1994); or Immolata Wetter, 'Mary Ward's Apostolic Vocation', The Way, supplement 17 (1972): pp. 69-91. It also had great impact upon teaching Orders such as the French Ursulines; see Philippe Annaert, Les Collèges au féminin: Les Ursulines; Enseignement et vie consacrée aux dix-septième et dix-huitième siècles (Namur, 1992); or Marie-Andrée Jégou, Les Ursulines du faubourg Saint-Jacques à Paris 1607-1662. Origines d'un monastère apostolique (Paris, 1981).

40 The revival of the English Benedictine Congregation began in 1607 and was made official in 1633 by Urban VIII's Bull known as 'Plantata'.

41 Claire Walker notes that 'One of the proponents of this school was Alfonso Rodríguez whose Practice of Perfection and Christian Virtues reduced Loyola's spirituality to conventional practicality'. See Gender and Politics in Early Modern Europe: English Convents in France and the Low Countries (Basingstoke, 2003), p. 141. 
Brussels had initially allowed Jesuit confessors, Abbess Joanna Berkeley ${ }^{42}$ soon wished to withdraw her community from the Society's influence. This provoked the outrage of some of the sisters, such as Lucy Knatchbull ${ }^{43}$ or Mary Roper Lovel, ${ }^{44}$ who decided to leave the house with the intention of founding a new one under the Society's direction. Although this early 1609 attempt failed, it foreshadowed the developments of 1624, when Lucy Knatchbull was part of a small group who left Brussels to found a new community in Ghent under the Jesuits' spiritual care. ${ }^{45}$ In the late 1620 s and early 1630s, the already troubled house in Brussels became divided into two clans: those who insisted upon Jesuit confessors and those who, on the contrary, would not have them. ${ }^{46}$

The Brussels dispute has been the object of fine studies, and it is not the purpose of this chapter to try to unravel the complex factors which caused such troubles in the community. ${ }^{47}$ It will suffice to say that this episode was revealing of the nuns' commitment to self-determination in matters of spiritual direction. If they were to 'kill the old Adam in [themselves]', ${ }^{48}$ religious women ought to be allowed to choose a method which was suitable to their personal inclinations and which they found helpful, rather than restrictive or burdensome. In the pursuit of appropriate means to seek divine love, some felt that the structure of the Ignatian Exercises did not bear fruit, and opted for a different type of spirituality. Thus, in Cambrai, the community came to reject Jesuit direction as unsuited to Benedictine life. In an echo of the complaints made by her sisters in Brussels, ${ }^{49}$ Dame Gertrude More explained that, though the Exercises were perfectly suited to the Jesuits, they were not at all so for enclosed nuns, since Loyola had

42 Joanna Berkeley (1581-1616), BB015.

43 Lucy Knatchbull (1611-29), BB107.

44 Mary Roper Lovel (1564-1628, left before her clothing).

45 The community at Pontoise - a daughter house from Ghent - later became another staunch defender of the method propounded in the Spiritual Exercises.

46 Claire Walker, 'Securing Souls or Telling Tales? The Politics of Cloistered Life in an English Convent', in Cordula Van Wyhe (ed.), Female Monasticism in Early Modern Europe: an interdisciplinary view (Aldershot, 2008), pp. 227-44.

47 Peter Guilday, The Catholic Refugees on the Continent, 1558-1795 (London, 1914); David Lunn, The English Benedictines, 1540- 1688: From Reformation to Revolution (London, 1980); Claire Walker, 'Securing Souls or Telling Tales?'.

48 Tobie Matthew (ed.), The Life of Lady Lucy Knatchbull (London, 1931), p. 394.

49 Agnes Lenthall had complained to Archbishop Jacob Boonen: 'the speret and derections of the fathers of the Societie of Jesus is quite diferent from the simplicities of our holye Rule, and that ther directions and examples hath wrought such effects that ther is little left since of the Rule of S Benedict amoungst us ... ', in AAM, Fonds Kloosters, Englese Benedictijnen/12, Agnes Lenthall to Jacob Boonen, 18 January 1629. 
devised his method for men in an active vocation, and never intended them for female contemplatives. ${ }^{50}$

Cambrai was somewhat atypical, since it was to develop its own unique spiritual identity. In July 1624, the newly established community had welcomed a member of the freshly restored English Benedictine Congregation, Augustine Baker (1575-1641), as their spiritual guide. During his nine-year stay, Baker transformed the spiritual course of the community, to the extent that Cambrai's very identity became known as 'Bakerite' and remained so long after Baker's departure in 1633 and his death in $1640 .{ }^{51}$ In this particular brand of spirituality, nuns were allowed to undertake their spiritual journey at their own pace, improving their contemplation gradually, according to their own capacities. ${ }^{52}$ Gertrude More expounded this flexibility, which she opposed to the Jesuit practices which 'all uphold the same form, and grow in all things too rigid for other Orders. ${ }^{53}$ Baker's way, she claimed, allowed her 'to reform [her]self in all inordinate affections to created things, and this more by quietness than by extraordinary force'. She believed with Baker that, if rid of its earthly hindrances, the soul would naturally follow its spiritual vocation and soar toward God. She wrote: 'If we should die unto ourselves / And all things else but Thee, / By natural impulse would our souls / Ascend and closely be / United to our Centre dear, / To which our souls would hie, / Because as proper then to us / As fire to upwards fly.' ${ }^{54}$

Gertrude More praised the simplicity of Baker's way, which sought to empty the penitent of all worldly emotions or representations, to allow her to be penetrated by the Holy Spirit. She implicitly criticized the Ignatian method when she wrote that 'every image of a created thing is an impediment to the said simplicity, and therefore it is to be rejected when the soul applieth itself immediately to God.' 55 Contrary to the Ignatians, Baker gave much leeway to the penitent soul to follow her own path, without relying on specific exercises or images. The nun was to abandon herself to God entirely. Through this vacuum, she became an expression of

50 The Writings of Dame Gertrude More, pp. 250-52.

51 On the subject of Augustine Baker's manuscripts and spiritual heritage, see Anselm Cramer, "The Librarie of the Howse": Augustine Baker's Community and their Books', in Analecta Cartusiana, 204 (2002): pp. 103-10; Claire Walker, 'Spiritual Property: The English Benedictine Nuns of Cambrai and the Dispute over the Baker Manuscripts', in Nancy E. Wright, Margaret W. Ferguson and A.R. Buck (eds), Women, Property and the Letter of the Law in Early Modern England (Toronto, 2004), pp. 237-55.

52 See David Lunn, 'Augustine Baker (1575-1641) and the English Mystical Tradition', Journal of Ecclesiastical History, 26.3 (July 1975): pp. 267-77.

53 The Writings of Dame Gertrude More, p. 251.

54 Ibid., p. 33.

55 Ibid., p. 229. 
the medieval 'empty vessel', a holy receptacle to be filled with the divine. ${ }^{56}$ One nun used this image in a lovely metaphor, urging her sisters to make themselves available to God: 'Thou art to be fild with good. Poure out the evell. Imagin that God would fill thee with hony: if thou art filld with vinegar, where wilt thou put the hony. ${ }^{57}$ This pure soul, or virgin spirit, became 'as a cleare glasse without spot' ${ }^{58}$ From this stage onwards, divine love would fill the soul entirely and make it ever purer, in a selfperpetuating process.

As the example of Cambrai illustrates, nuns strongly believed that the wrong type of guidance was likely to hinder their spiritual journey and to foster worldly emotions - such as frustration, desperation, anger and fear - all of which conspired to keep them away from the one, perfectly spiritual emotion which they sought: divine love.

\section{Divine Love as the Ultimate Spiritual Emotion}

On the way to perfect union with their heavenly bridegroom, women religious practised devotional exercises meant to effect a deep change in the inner portion of their souls. Yet despite their best efforts to soar towards the divine, they remained beings of flesh and blood; time and again, they bemoaned this obstacle to mystical union, this flesh upon the wings of the soul 'which makes it unable to fly'. ${ }^{59}$ The Platonic image of the soul as entombed in the body was recurrent in their writings; Gertrude More, for instance, referred to her carnal shell as a 'grievious burden of flesh and blood' ${ }^{60}$ Later, Christina Brent lamented: 'The bodie is my onlie burden.' ${ }^{61}$ Since the body was such a hindrance to contemplative perfection, many nuns looked forward to death as a happy moment, a long-awaited passage to a better state where they would be free from the slavery of base human emotions. One author argued that those who truly love God 'court eternall life, they lament the delay'. ${ }^{62}$ Death, the object of so much trepidation in most living creatures, became a desirable liberation, a liminal moment in which the nun would finally be born unto her spiritual self. Gertrude More, in her exercises, envisaged her own death as a deliverance: 'who

56 See Caroline Walker Bynum, Holy Feast and Holy Fast: The Religious Significance of Food to Medieval Women (Berkeley and Los Angeles, CA, 1987).

57 ADN, Ms 20H-40, writings on Love, 'God is to be loved before all things' (item 2).

58 Ibid., item 10.

59 ADN, Ms 20H-40, item 23.

60 Gertrude More, The Holy Practices of a Devine Lover, p. 56.

61 ADN, Ms 20H-10, f. 287.

62 ADN, Ms 20H-40, Writings on Love, item 4. 
shall deliver mee from the Bodye of this Death? ... I desire to be dissolved, and to be with Christ.' To her, this life on earth was a time of trial and spiritual death and, in reverse, she expected her physical death to usher her spiritual renaissance in perfect union with her heavenly spouse. She longed for death, which alone would allow her finally to know divine love: 'When shall this earthly Tabernacle be dissolved, and my soule be made one with thee?'63 Such rhetoric was common in the devotions of early modern religious women, and typical of the Benedictines of Cambrai.

For the accomplished religious, death was therefore not a source of anxiety or fear, since it put a stop to decades of slavery to the body, its distempers, and its vile natural emotions. Death heralded the beginning of a truly spiritual fulfilment in which the nun, united with God, would experience the only supremely worthy emotion of divine love. On her deathbed, the zealous contemplative took care 'to dispose her soule for the sweet embraces of her heavenly spows' ${ }^{64}$ before she 'passed to her reward' or 'rendered her pious soul into the hands of her creator' ${ }^{65}$ From this perspective, death was understood as freeing, since it allowed, finally, the full experience of divine union. ${ }^{66}$

It was when contemplating this blissful prospect of disembodied divine union that nuns resorted to the most affective language to be found in their manuscripts. In evocation of their bridegroom, in expectation of his love, these censors of worldly passions wrote with nothing less than intense emotions. 'O my Happynesse! O my only delight! O joye of my hart! O my Hope, my sollace, my beginninge, and end!' ${ }^{67}$ The breathless rhythm of Gertrude More's short interjections combined vividly with the repetition of exclamation marks to communicate the ardour of her emotions and the fire of her desire for her divine lover. With the reiteration of the pronoun 'my', More expressed her affective bond with her God, her sense of belonging to Him, and of being nothing but Him. ${ }^{68}$ In the happy state she dreamed of, after her liberation from human weakness and debilitating

63 Augustine Baker (ed.), The Spiritual Exercises of the Most Vertuous and Religious D. Gertrude More, pp. 139 and 150 respectively.

64 'Abbess Neville's Annals of the Five Communities', ed. Mary Justina Ramsey, CRS, 6 (London, 1909), p. 31; Eugenia Pulton's obituary.

65 Obituary of Mary Vavasour, in Obituaries of the Brussels Benedictines, Downside Abbey, ff. 90-91. On the functions of obituary writing in the convent, see Caroline Bowden, 'Collecting the Lives of Early Modern Women Religious: Obituary Writing and the Development of Collective Memory and Corporate Identity', Women's History Review, 19.1 (2010): pp. 7-20.

66 Gertrude More, The Holy Practices of a Devine Lover, p. 68.

67 Baker, The Spiritual Exercises, p. 152.

68 See Marion Norman, 'Dame Gertrude More and the English Mystical Tradition', Recusant History, 15.1 (May 1979): pp. 196-211. 
passions, her 'Happynesse', 'delight', 'joye', 'hope', or 'solace' all sprang from union with Jesus Christ and were therefore divine in nature, to be differentiated from the baser kinds of natural emotions. Such heightened feelings were the goal for which all zealous nuns yearned in their pursuit of spiritual perfection and divine love. More's co-sister, Margaret Gascoigne, also proclaimed her longing for this holy union:

Yet art thou my most true Lord \& lover, \& I will yet farther presume to say, $\&$ againe $\&$ againe to say, that thou art hee whom my soule desireth, longeth, $\&$ coveteth to love ... Come, O come, my most sweet Lord, into the garden of my soule, \& gather the fruites of my labour; Come I beseech thee, on whom I desire to bestow the fruites of all mine actions. ${ }^{69}$

In Gascoigne's writings, the word 'desire' featured recurrently, as did evocations of ardour, yearning, longing and pining. The same longing was also expressed poignantly in this anonymous document:

O my dearest Lorde and my God, O my best beloved spouse and friend choosen above all others. O my love, my refuge, my joy, and whatsoever my heart can desire?... O that my soule with all its powers myght perfectly be united unto thee, never more to be separated from thee, but allwaise to rest in thee, that so enjoying thy sweet embraces it may be drowned and melted into thy owne divine substance. ${ }^{70}$

In this passage, as in so many others, the nun conveyed her anticipated happiness at the time of her intimate union with the divine lover through highly sensual prose in which she called upon all of her senses to represent the perfection of her bliss. Thus, she could feel her bridegroom's 'sweet embraces' and through the common metaphors of drowning or melting, she merged entirely with God and became lost in His immensity. Gertrude More used the same images when she wrote of being 'drowned and swallowed up in that ocean of Divine Love' or of melting away through the excess of her passion. ${ }^{71}$ She yearned to be penetrated and filled by divine love and she called, breathless: 'O love! love! flow into my soul that I may sigh and pant after God alone and praise this my Beloved for all eternity! 72

Such emotive prose was typical of that left by her Benedictine sisters at Cambrai, and it echoed the rich heritage of the European mystics who have

\footnotetext{
69 Ibid., p. 58.

70 ADN, Ms 20H-37, On the Love of God, f. 185.

71 The Writings of Dame Gertrude More, p. 77.

72 Ibid., p. 108.
} 
fascinated both historians and literary scholars for decades. Divine love was, in turn, a burning furnace of love, a dart piercing the heart through and through, an ocean in which to swim or drown, or a vivifying fountain at which to quench one's spiritual thirst. These images were reminiscent of those used by holy exemplars such as St John of the Cross, or Teresa of Avvila. Through the ages, mystical union with God was ever expressed in the language of the senses and emotions. The physical and affective nature of the mystical experience was actually one of the reasons why the clerical authorities of Teresa's Spain held the alumbrados in the highest suspicion, and why Teresa herself had to prove the godly origin of her ecstasies. ${ }^{73}$

The emotive expression of the spiritual experience of divine love was as mysterious to contemporaneous witnesses as it is now. Modern studies of mysticism have duly noted the vibrant sensuality, or indeed the eroticism, of the accounts documenting mystical encounters with God. ${ }^{74}$ Yet, the nuns' amorous longings and their experiences of divine penetration may not be best interpreted as sexual arousal or indeed orgasmic pleasure. ${ }^{75}$ These modern and secular readings fail to take into account that the religious women who felt such physical expressions of their union with God experienced them as entirely different from animal appetites. As the brides of Christ sought to unite with their heavenly bridegroom, they were consumed by a desire which far transcended any human love: these were the spiritual affects of spiritual creatures. ${ }^{76}$ If any confusion between divine love and its base human counterpart was permitted, the fault lay with the very limits of human language, since divine lovers had no other words but those of earthly love to express their spiritual transports. Those were constraints which could not be overcome. Reflecting upon this seeming contradiction, French philosopher Simone Weil once wrote that 'To reproach mystics with loving God by means of the faculty of sexual love is as though one were to reproach a painter with making pictures by means of colors composed of material substances. We haven't anything else with which to love. ${ }^{77}$ And indeed, many times did nuns lament the

73 See Gillian T. W. Ahlgren, Teresa of Àvila and the Politics of Sanctity (Ithaca, NY, 1996), p. 15; and Stephen Haliczer, Between Exaltation and Infamy: Female Mystics in the Golden Age of Spain (Oxford, 2002).

74 Amongst others, see Amy Hollywood, Sensible Ecstasy: Mysticism, Sexual Difference and the Demands of History (Chicago, IL, 2002); Elizabeth Petroff, Body and Soul: Essays on Medieval Women and Mysticism (New York, 1994).

75 Caroline Walker Bynum (ed.), Fragmentation and Redemption: Essays on Gender and the Human Body in Medieval Religion (New York, 1992), p. 86.

76 Thomas Dubay, S.M., Fire Within: St. Teresa of Àvila, St. John of the Cross, and the Gospel - On Prayer (San Francisco, CA, 1989), p. 41.

77 Simone Weil, The Notebooks of Simone Weil, trans. Arthur Wills (2 vols, London, 1956), vol. 2, p. 472. 
inadequacy of such words to convey divine emotions; Gertrude More herself remarked: 'Who can express what passeth between such a soul and Thee? verily neither man nor Angel is able to do it sufficiently. ${ }^{78}$ What was expressed in the language of emotions was in fact experienced on a different level altogether, spiritually, and that only when the bride of Christ had managed to eradicate her own, human passions. Successful nuns became one with their God by transcending the humours or passions of this mortal coil. In this heightened spiritual experience, Augustine Baker explained, 'The soul is now so elevated in spirit that she seems to be all spirit, and, as it were, separated from the body. ${ }^{79}$

Thus it appears that the early modern understanding of emotions or 'passions' as the undesirable affects of distempered bodies led religious women to consider feelings as contradictory with a contemplative vocation. Helped by their monastic vows, and guided by prescriptive literature and clerical advice, zealous nuns tried to root out emotions from their lives: they cut themselves off from the pleasures of the world, forsook personal friendships and sought humility in an effort to experience the affective vacuum which alone could allow them to be entirely receptive to divine love. This life on earth was a time of trials where contemplatives attempted symbolically to die to the world's physicality, which kept them away from their spiritual rebirth in Christ; yet there was hope, for successful abstraction from emotions was rewarded with divine union:

... as soon as the world is cast forth $\&$ the heart is cleansed from all longation of $\operatorname{sinn} \&$ affection to creatures, presently the entire satiating $\&$ ravishing Love of the eternal spouse Jesus Christ Crucified enters and takes full possession thereof. ${ }^{80}$

Women religious' rapport with emotions was, however, more complex than this dichotomy between evil, worldly feelings and godly, spiritual affects. In the case of the Bakerite spirituality embraced by the English Benedictines of Cambrai, union with God was experienced in highly physical, emotive ways. The Cambrai nuns owed much to the mystical heritage of earlier times and although they themselves did not report divine visions, raptures, or ecstasies, they partook of the same movement which valued an immediate (unmediated) experience of divine love. What they felt during moments of perfect prayer, in contemplation of their heavenly bridegroom, was by necessity experienced through the body and

\footnotetext{
78 Ibid., p. 8.

79 Augustine Baker, in Contemplative Prayer, p. 412.

80 ADN, Ms 20H-17, A Short Treatise on the Three Principall Vertues and Vows of Religious Persons, ff. 122-23.
} 
its emotions. Although these spiritual emotions were construed as entirely distinct from animal passions, they did find their source in the body, and expressed themselves in joy, tears, or sensory images such as burning or drowning. Hence, it seems that the corporal shell which nuns sought to subjugate - or even to escape altogether - if it could be a hindrance to contemplative perfection, could also be the very locus of the experience of divine love, and the opportunity for spiritual bliss. 
Copyright material: You are not permitted to transmit this file in any format or media; it may not be resold or reused without prior agreement with Ashgate Publishing and may not be placed on any publicly accessible or commercial servers. 